\title{
My Resent Research
}

by

\section{Akio YONEZU*}

会員便りの執筆の機会を頂き, 僭越ながら「最近の私 の研究紹介」をさせて頂きますが, 折角ですので材料学 会会員の思い出を少し回想させていただきます、私は, 機械工学の材料力学・強度学に関する研究を行っており, 材料学会は私の中で一番早くに入会した学会で, すでに 13年以上が経過しました。年の間，所属機関も変わり， 青山学院大学で 5 年, 大阪大学で 5 年, そして今の中央大 学で 4 年が経ちましたが, どの機関においても材料学会 には大変损世話になったと実感でき, 思い出深い学会で す. 本学会では, 講演会のような情報交換の場はもとより, 部門委員会や支部活動の運営にも積極的に関わることが でき, 自分の研究活動以外の様々な経験もできた学会と 思います。例えば, 部門委員会は伝統があり, 企業委員 も多く, 学術研究のみならず, 現場での問題, 産業界と の関わりも多く学ぶことができました，また，関東支部 では機械工学以外の土木, 建築, 材料といった様々な分 野の方々と深く交流でき, 自分の研究領域外の新鮮な情 報や異なった文化にも自然と触れられ，色々と刺激になっ たと感じています。 この面は, 大学での講義や教育面に おいても貴重な知見となり, 現在は材料学会の「機械材 料学」教科書も使用しながら, 専門的内容とその産業界 の関わりを講義でき，履修学生からも好評なようです。

このご時世, 私も含め $20 \sim 30$ 歳代の若手研究者は, 研究業績や競争的資金など自身の研究に直結する事柄に 集中するのは当然かもしれませんが, 上記のような経験 も将来のキャリア形成において大事ではないかと認識し てきました，本学会は，専門分野を深く議論する場でも あるとともに, 自然と様々な分野にも触れられるので, 視野を広げる機会でもあったのではないかと感じており ます。そそれは, 所属機関においても, 異動においても, 自身の教育・研究においても, 何らの形で良い影響をも たらしてくれると思っています。

そのようなこともあり, 中央大学に移籍してからは, 少しずつ視野 (研究分野) を広げる意識も持ちはじめ, 自分の専門性を他分野にも生かせないかと考元始めまし た．実際に中央大学では，「共同研究プロジェクト」とい う研究資金の支援制度があり, 分野の異なる研究室間（と きには学科間や学部間）の共同研究を推進するオープン な文化もあることから，それに関連した最近の研究を， ここで紹介させていただきます（同時期に着任した先生
（膜分離，高分子化学が専門）との雑談からスタートした 研究ですが，あまり進んで㧍らず未発表）

海水淡水化や浄水 -下水処理に用いられる水処理膜や 逆浸透膜（RO膜）は, 有機物や微生物が堆積して膜孔を 閉塞さるファウリングが課題であり, ランニングコスト

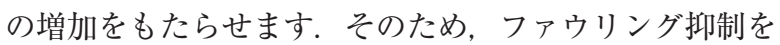
目的とした膜創製法や表面改質技術，前処理や洗浄法な ど様々な検討がなされ，またファウリング成長プロセス も報告されています（例えば, Khanら Environ. Sci. Technol. 2013). 万過中には様々な有機物の吸着とそれに 伴う微生物の吸着（增殖）が相互的に進行する説が提唱 され，例えばフミン酸，多糖，タンパク質の有機物が, それぞれの段階でプランクトンやプロテオバクテリアと いった微生物の吸着と増殖をもたらすことから, 原因物 質も多様であり，また継時的に変化するようなので， メ カニズムは複雑です，そこで本研究では，このような吸 着現象を材料強度学の観点から解明することを目指しま した，具体的には，図のように原子間力顕微鏡 (AFM) を用いて溶液中での微小な吸着力測定を行い,ファウリ ング物質の吸着力やその経時変化を捉えることで, 成長 プロセスの解明や成長速度，そしてファウリング抑制の ための前処理法や洗浄法を検討することを目指しており ます，実験では，図のと扔り様々な有機物を想定し，そ の官能基を修飾させた $\mathrm{AFM}$ プローブを自作して, 吸着力 測定に用います。ささらには, 吸着挙動に対する分子構造 モデリングの接触力学を検討しはじめ, 今後は実験結果 の解釈とファウリング制御法を提案していく予定です.

今後も視野を広げ，少しずつではありますが，新たな 分野にも挑戦していきたいと思っています。
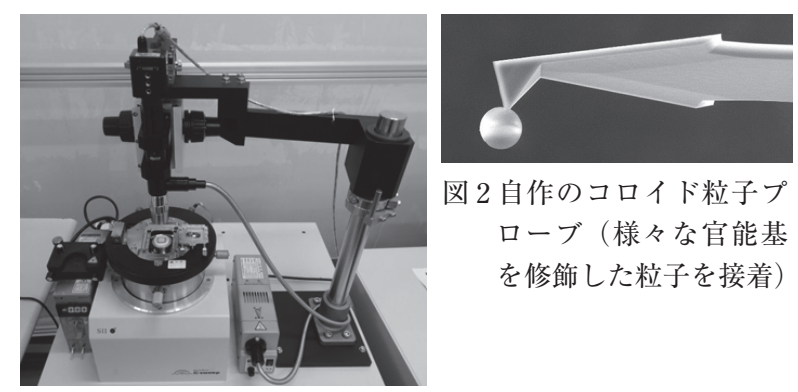

図 2 自作のコロイド粒子プ ローブ（様々な官能基 を修飾した粒子を接着)
図 1 原子間力顕微鏡, 溶液中で のフォースカーブ測定（吸 着力測定） 